\title{
An evaluation of slaughterhouse wastes in south-west Nigeria
}

\author{
D. O. Omole*, A. S. Ogbiye \\ Department of Civil Engineering, Covenant University, Ota, Ogun State, Nigeria
}

Email address:

david.omole@covenantuniversity.edu.ng(D. O. Omole)

To cite this article:

D. O. Omole, A. S. Ogbiye. An Evaluation of Slaughterhouse Wastes in South-West Nigeria. American Journal of Environmental Protection. Vol. 2, No. 3, 2013, pp. 85-89. doi: 10.11648/j.ajep.20130203.12

\begin{abstract}
This study was carried out at ten randomly selected slaughterhouses situated in Lagos and Ogun States, Nigeria. The aim was to evaluate the current waste generation and waste handling practices while exploring the possibility of reducing to the barest minimum the percentage of live weight cow that is considered as waste. This was achieved through questionnaire application, live interviews, literature review and physical inspection. It was shown that just $5 \%$ of the total slaughtered animal weight, arising from bovine blood, dung and undigested paunch contents, coupled with the large volume of water required to wash off this small percentage of animal parts constituted the greatest proportion of environmental problems associated with slaughterhouse operations. Ways through which these waste materials could be converted into wealth, thereby relieving the environment from their harmful effects were suggested.
\end{abstract}

Keywords: Slaughterhouse, Solid Waste, Cattle, Wastewater, Regulation

\section{Introduction}

Waste generation at Nigerian slaughter houses poses a serious threat to the environment because of poor handling practices which result into adverse impact on land, air and water. In a typical Nigerian abattoir, the surrounding land is often marshy due to improper channelling of wastewater arising from the dressing of the slaughtered animals and washings at the lairage. Land pollution also occurs when solid wastes such as bones, pieces of flesh and dung are left unattended in open spaces. When precipitation takes place, these wastes leave the land in a polluted state while part of it get washed into nearby streams. Most Nigerian abattoirs are situated close to surface water bodies in order to have access to water supply needed for slaughtered animal processing and to provide a sink for the run-off from meat processing activities [1]. Studies carried out at sixteen slaughterhouses in Ireland placed the needed average volume of water for processing slaughtered cattle at approximately $2 \mathrm{~m}^{3} /$ head and, between $80-95 \%$ of this is returned as wastewater [2]. When this is multiplied by the number of cattle slaughtered per day, this constitutes a large volume of liquid waste. Wastewater from slaughterhouses is known to cause an increase in the biochemical oxygen demand (BOD), chemical oxygen demand (COD), total solids (TS), $\mathrm{pH}$, temperature and turbidity of surface water bodies due to blood and paunch contents being washed off the slaughtered animals [1, 3]. Raw bovine blood is known to have COD values in excess of $375,000 \mathrm{mg} / \mathrm{L}$ while COD from the animal dung was put at $15,000-30,000 \mathrm{mg} / \mathrm{L}[1$, 4]. Whereas the recommended limit of COD in treated wastewater before discharge into surface water bodies is put at $125 \mathrm{mg} / \mathrm{L}$ [5], bovine blood and paunch contents are oftentimes washed away without any form of treatment into nearby streams. This constitutes very strong organic load for surface water bodies. The effect of this is the depletion of dissolved oxygen (DO) content of the surface water body and the attendant imbalance and/or loss of aquatic life [6]. In a study conducted on five slaughterhouses in Ibadan, Nigeria, it was found that Total Suspended Solids was between 590 to 1050 times the accepted limited [17].

Furthermore, the air around slaughterhouses is often offensive due to putrefying flesh and odour molecules such as ammonia, amines, sulphur compounds and fatty acids arising from rendering activities [2]. It is also common practice to render animal parts in the open by wood burning in the place of boilers which are used in developed countries. This contributes carbon dioxide, a known greenhouse gas, to the atmosphere. A major contributing factor to high volumes of waste generation and difficulty in waste management at Nigerian slaughterhouses is the 
absence of preservation facilities such cold rooms. This, in turn, is connected to the poor energy generation capacity of Nigeria in general. Therefore, all slaughtered animals must be sold off same day. Any unsold part becomes a waste or is ineffectively preserved and the cycle continues the next day. In the light of this, it is observed that if there is a possibility of re-using every part of the slaughtered animal, environmental pollution can be minimized to the barest minimum.

Animals slaughtered at Nigerian abattoirs include cows, sheep, goat, pigs and chickens. However, since the wastes from cattle are nearly ten times as much as wastes from goats or sheep [8], the current study therefore focused on cattle wastes. Furthermore, the pre-dominant cattle specie in Nigeria is Zebu. The Zebu specie has six sub-species of which the White Fulani (also known as Bunaji) is the most common since it constitutes $36 \%$ of national herd [9-11]. The average weight of the White Fulani is $350 \mathrm{~kg}$ [11]. For this reason, this value was adopted for analysis in this study. The parts of the typical slaughtered cattle by weight are presented in Figure 1.

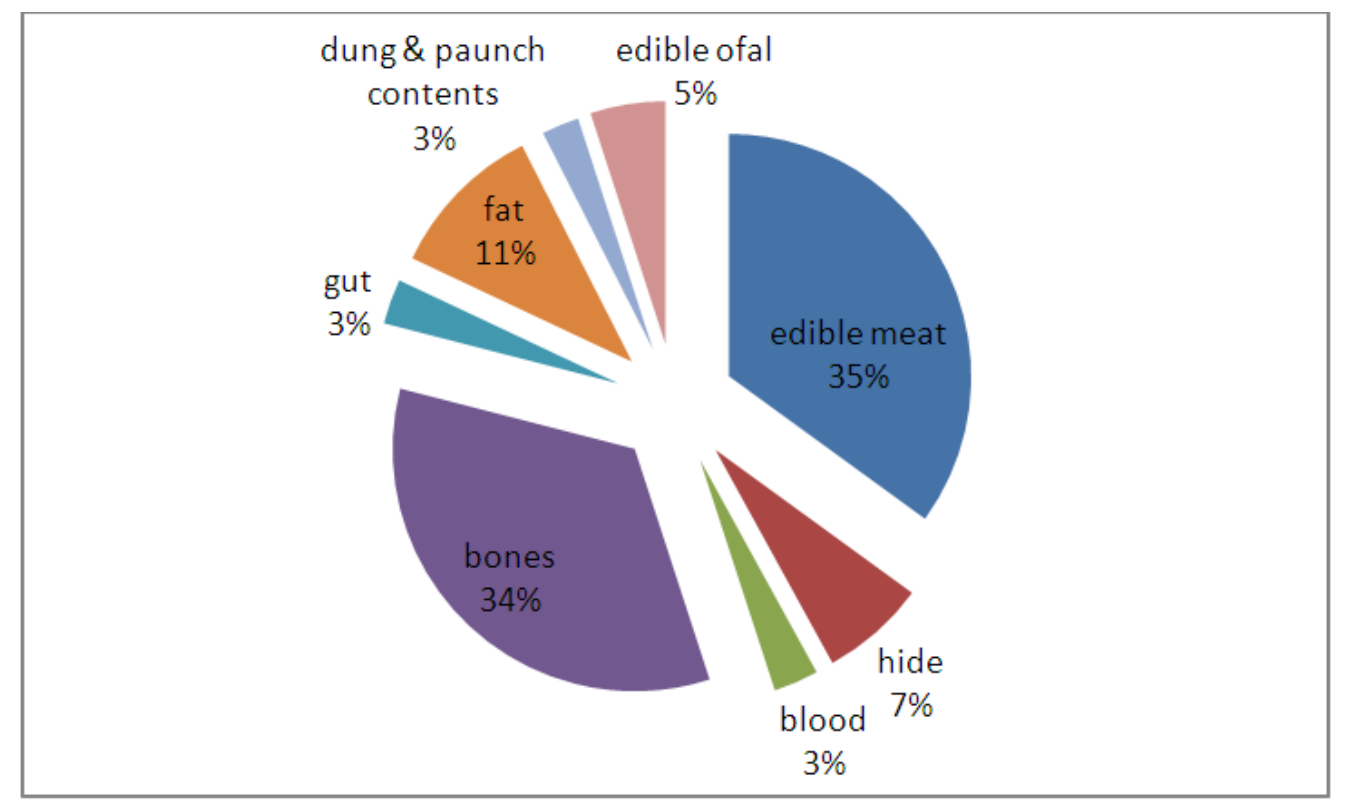

Figure 1. Statistics of bovine body parts

The average weight of the slaughtered White Fulani cattle can be categorized into eight parts. Edible meat realizable from the slaughtered cattle is $122.5 \mathrm{~kg}$ while edible offal made up of heart, lungs kidney, tongue and liver amounts to about $19.2 \mathrm{~kg}$. The bones, made up of skeleton, head, horns, hooves and feet constitute the second largest part by weight of the cattle. The blood and other body fluids weighs around $10.5 \mathrm{~kg}$ and the gut made up of the intestines and stomach weighs the same. The animal hide weighs about $24.5 \mathrm{~kg}$. The dung and undigested paunch contents weigh the same as the gut while the fat, both edible and inedible weigh about $36.7 \mathrm{~kg}$ [1-2; 12-14].

This study examines current practice in selected abattoirs within Lagos and Ogun States of Nigeria in order to determine the sources of slaughterhouse wastes and to explore the ways by which slaughterhouse wastes in Nigeria can be minimized.

\section{Method}

\subsection{Study Area}

This research was carried out between August to September 2011 at ten slaughterhouses, six of which are situated in Ogun State and four in Lagos State, Nigeria. The two states share the same boundary and are located within the south-western part of Nigeria. Ogun and Lagos States had a population of 3.7 and 9.01 million people respectively in the 2006 census. However, with a growth rate of $6-8 \%$ and current population of 18 million people, Lagos State is the second fastest growing city in Africa and the sixth fastest growing city in world. [15-17]. This translates into increasing demand for meat protein. Simple random technique was adopted in sourcing information from workers at the slaughterhouses. These sampled population included butchers, cattle traders, meat sellers and transporters. Among the six sampled abattoirs in Ogun State, four are situated in Ado-Odo/Ota Local Government area (LGA) of Ogun State, one is situated at Ifo LGA (Onihale) and another abattoir at Abeokuta. Ado-Odo/Ota, Ifo and Abeokuta LGAs were targeted for sampling because they are the most populated local government areas in Ogun State [15]. The sampled slaughterhouses in Lagos state included two in Agege LGA, one slaughterhouse in Alimosho LGA (Ayobo) and another at Ibeju-Lekki LGA. The study locations were varied in size of operations. Information gathered from each abattoir included the average number of animals slaughtered per day, the method of disposal of the different parts of the slaughtered animal, 
perception on economic values of some parts of the slaughtered animals presently being discarded as wastes, and the willingness of the abattoir operators to cooperate with any future project that may help in reducing abattoir wastes. The gathered data were analyzed using descriptive statistics and Microsoft Excel in windows office suite.

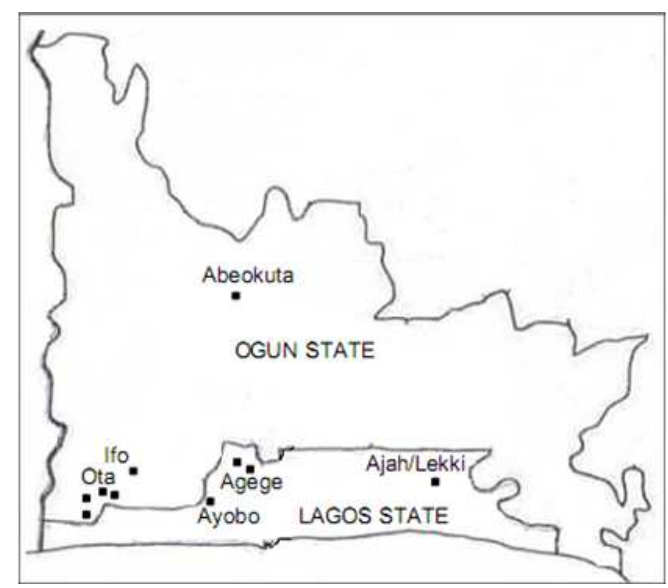

Fig 1. Study Area

\section{Results and Discussion}

The capacities of the sampled slaughterhouses as well as uses to which animal parts are subjected are presented in Table 1. While most of the slaughterhouses had very little carrying capacity, the Oko-Oba-Agege and RandaAbeokuta slaughterhouses accounted for approximately $97 \%$ of the cattle slaughtered in all sampled abattoirs. The former slaughterhouse is the largest, not just among the sampled population but also in Nigeria [9]. This is understandably so considering the population of Lagos State.

Table 1. Data Summary

\begin{tabular}{|c|c|c|c|c|}
\hline \multirow{2}{*}{$\mathbf{s} / \mathbf{n}$} & \multirow{2}{*}{ Location } & \multirow{2}{*}{$\begin{array}{c}\text { capacit } \\
\mathbf{y}\end{array}$} & \multicolumn{2}{|c|}{ uses of the animal parts } \\
\hline & & & blood & dung/paunch \\
\hline S1 & Canaanland & 2 & $\begin{array}{c}\text { dispose } \\
\mathrm{d}\end{array}$ & disposed \\
\hline $\mathrm{S} 2$ & Ota/(Osi round about) & 1 & $\begin{array}{c}\text { dispose } \\
\mathrm{d}\end{array}$ & disposed \\
\hline $\mathrm{S} 3$ & Ota (Atan) & 3 & $\begin{array}{c}\text { dispose } \\
\mathrm{d}\end{array}$ & disposed \\
\hline S4 & Agege (Abattoir) & 1200 & sold & sold and disposed \\
\hline S5 & Ajah/Lekki & 10 & $\begin{array}{c}\text { dispose } \\
\mathrm{d}\end{array}$ & disposed \\
\hline S6 & Ayobo & 7 & $\begin{array}{c}\text { dispose } \\
\mathrm{d}\end{array}$ & disposed \\
\hline S7 & Onihale /Ifo & 3 & $\begin{array}{c}\text { dispose } \\
\mathrm{d}\end{array}$ & sold \\
\hline S8 & Agege (Pen cinema) & 4 & sold & sold \\
\hline S9 & Ota (Toll gate) & 10 & sold & sold \\
\hline $\mathrm{S} 10$ & Abeokuta (Randa) & 60 & $\begin{array}{c}\text { dispose } \\
\mathrm{d}\end{array}$ & sold \\
\hline
\end{tabular}

Data analysis indicated that in all the ten sampled abattoirs, $95 \%$ of the slaughtered cattle, comprised of edible meat, edible offal, bones, gut, fat and hide, are fully utilized and hardly go to waste. All the bones, hooves and horns $(\mathrm{BHH})$ are exported to foreign countries where they are used for the manufacture of plates and buttons. The $\mathrm{BHH}$ which is calcium rich is also used locally in the production of poultry feed and pet food (Fig. 2). The hide is exported for further processing into leather products such as drums, hats, horse whips etc. Also, the hide and offal are consumed locally as delicacies. Similarly, all the animal fats were found to be put to a variety of uses. Such uses include direct consumption by humans, production of cooking oils, production of pig-food supplements, and as fuel for lamps and wood-lit fires.

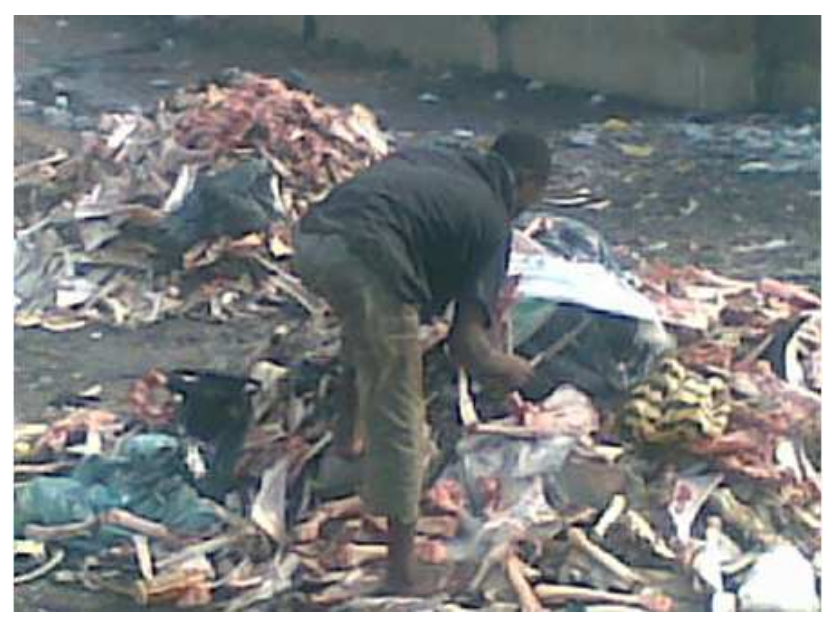

Figure 2. Bones, hooves and horns being dried and sorted for sale

The remaining $5 \%$ of the parts of the slaughtered animal which had varied fate are the animal blood, body fluid, dung and paunch contents. These minute parts by weight of the slaughtered animal are mostly responsible for the greater proportion of wastes generated in Nigerian abattoirs. Of the sampled population, only $30 \%$ re-used bovine blood. Such uses are mainly for the production of pig and fish food. Other respondents dispose the animal blood into the environment. Considering the strength of raw bovine blood and the volume of water required to wash it off the animal, the apparently small proportion of the slaughtered animal becomes magnified at the point of disposal. Similarly, only $40 \%$ of the sampled population re-used the dung and undigested paunch contents from the animals. They are dried and sold off for use as manures,

The operations at Oko-Oba Agege abattoir are largely regulated by the Lagos State government officials, thus contributing to the relatively sanitary conditions observed at the abattoir. The operators also try to re-use all the parts of the animal thus drastically reducing the waste generated. However, the environment around the abattoir is still characterized by highly pungent odour emanating from putrefying flesh and surface water bodies polluted by wastewater from the abattoir. This is because some of the operators still manage to deviate from stipulated 
regulations. Due to the large numbers of animals slaughtered per day, shortage of preservative facilities and equipment at the abattoirs, and the need to maximize sales and distribute the product to different parts of the State, animal stunning are done mostly before dawn. The regulatory officers arrive during official work hours in the morning after most of the animals have been slaughtered.

When questioned on level of awareness on ways to reduce the pollution in the environment, $30 \%$ of the respondents had no idea whatsoever of ways to re-use the dung from the slaughtered animals. However, all the respondents indicated interest and willingness to cooperate with any project that could help achieve higher efficiency in waste reduction. Aside the answered questionnaires, physical observations reveal that a lot still has to be done in improving on the efficiency of waste material re-use.

When the weight of all the blood that are washed into the environment at the different abattoirs were added together and compared with the weight of all the animal dung/partially digested food that are thrown away, it was found that the blood constituted a larger proportion of the most unwanted parts of the slaughtered animal and therefore becomes the most difficult abattoir waste to deal with (Figure 3). Bovine blood is the reason why a lot of wastewater is generated during animal rendering. Therefore, special attention needs to be given to this particular waste.

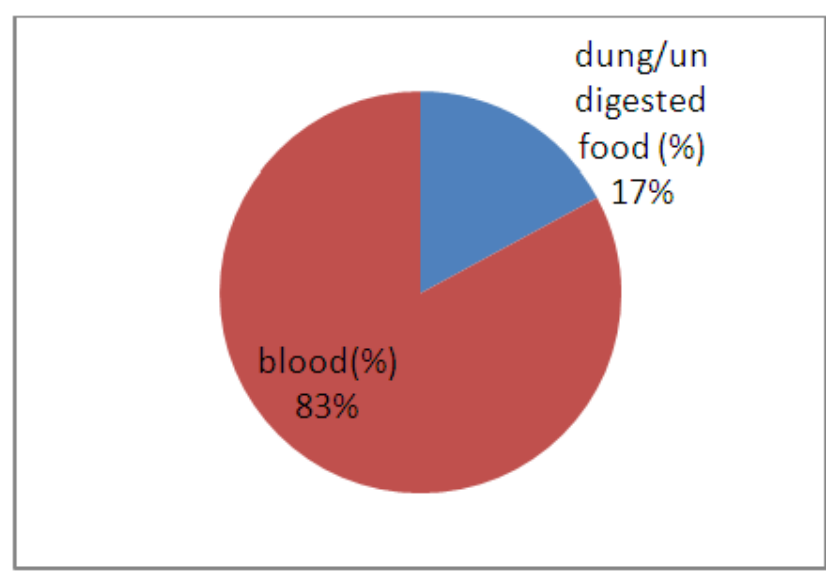

Figure 3. Difficult wastes by percentage

\section{Conclusions}

The dung, paunch contents and blood which represent just $5 \%$ of the total cow slaughtered at abattoirs constitutes the greatest threat to the environment. Therefore, research should be directed at finding ways to re-use these animal parts. Local industries should be encouraged in the re-use of animal fat and blood. This will help reduce the waste, loss of foreign exchange and increase employment opportunities. It was observed that human consumption of the animal fat is rampant. This practice should be discouraged because of its negative effect on human health. Other avenues of fat usage such as in cosmetic and pet food production should however be encouraged. Also, private investors should recognize the opportunities presented by the absence of preservative facilities at the numerous abattoirs all over Nigeria. The waste materials such as bovine blood and paunch contents could be used to generate biogas energy which in turn can be used to power cold rooms for meat preservation. The generated energy could also be useful for rendering the slaughtered animals as a replacement for the current practice of open fire which can lead to fire disasters, respiratory problems and carbon monoxide generation. The excess gas can be sold to other users thereby generating additional revenue and most importantly, the stench that arise from this organic matter will be eliminated. None of the bovine blood should be allowed to get washed into the nearby surface water bodies. It should be collected and sold or given out to those who use them for fish and pig food supplements. Furthermore, the presence of regulatory officials at the slaughterhouses has a lot of impact on practices by the operators. Municipal authorities should explore ways to ensure that such practices are monitored regardless of the time of day. Also, the few clusters of abattoirs with low capacities may be merged into major abattoirs to facilitate ease of supervision by regulatory officials.

\section{References}

[1] Omole, D.O. and Longe, E.O. (2008). An Assessment of the Impact of Abattoir Effluents on River Illo, Ota, Nigeria, Journal of Environmental Science and Technology, 1 (2), 2008, pp. 56-54.

[2] Enterprise Ireland (2009). Sustainable Practices in Irish Beef Processing. National Development Plan, Government of Ireland.

[3] Ezeoha, S.L. and Ugwuishiwu, B.O. (2011). Status of Abattoir Wastes Research in Nigeria. Nigerian Journal of Technology, 30(2): 143-148.

[4] Tritt W.P. and F. Schuchardt (1992). Materials flow and possibilities of treating liquid and solid wastes from slaughterhouses in Germany, Bioresource Technology 41, 1992, pp. 235-245.

[5] Environment Canada, EC (1998). Sampling for Water Quality. Ministry of Supply and Services, Canada.

[6] Longe, E.O. and Omole, D.O. (2008), Analysis of Pollution Status of River Illo, Ota, Nigeria. The Environmentalist, 28: 451-457.

[7] Sangodoyin, A.Y. and Agbawe O.M.(1992). Environmental Study on Surface and Groundwater Pollutants from abattoir effluents, Bioresource Technology 41, 1992, pp. 193-200, Elsevier Science Publishers Ltd, England.

[8] Aniebo A.O, Wekhe S.N. and Okoli I.C. (2009). Abattoir blood waste generation in River state and its environmental implications in the Niger Delta. Toxicological and Environmental Chemistry 91, 619-625.

[9] Ademola, A.I. (2010). Incidence of fetal wastage in cattle slaughtered at Oko Oba abattoir and Lairage, Agege, Lagos, 
Nigeria. Vet. Research 3(3): 54-57.

[10] Blench, R. (1999). Traditional livestock breeds: geographical distribution and dynamics in relation to the ecology of west Africa.Overseas Development institute, London.

[11] Opara, M. N., E. C. Nwachukwu, O. Ajala, and I. C. Okoli (2006). Effects of Breed and Weight on the Reproductive Status of Zebu, Cows Slaughtered in Imo State Nigeria. Life Science Journal, 3 (3): 77-81.

[12] Blakely, D. (2009). Cull Cow Body and Carcass Composition, Ministry of Agiculture, food and rural affairs, 2009. Available at http://www.omafra.gov.on.ca/english/livestock/beef/facts/05 -075.htm. Accessed 24th September 2011

[13] Scahill, D., (2003). Cow weight/cow meat ratio. Available at: http://www.experts.about.com/q/Food-Science-1425/cow weight-cow meat.htm. Accessed 24th September 2011.

[14] Verheijen, L.A.H.M., D. Wiersema, L.W. Hulshoff Pol and J. DeWit, (1996). Management of Wastes from Animal Product Processing. International Agriculture Center, Wageningen, The Netherlands.

[15] NBS (2007). 2006 Population Census. National Bureau of Statistics, Federal Republic of Nigeria. Available at http://www.nigerianstat.gov.ng/Connections/Pop2006.pdf. Accessed 7th May, 2009.

[16] Akinfolarin, B. O. and Okubanjo A. O. (2010). Human population growth rate and meat supply in Lagos state (1991-2000). acta SATECH 3(2): 19 - 24.

[17] LWC, (2011). LWC targets 733 million daily by 2020 . Retrieved from: http://www.lagoswater.org/news.php?page=45. Accessed on: November 21, 2012. 